\title{
Shared routes of mammalian kinship: Race and migration in Long Island whaling diasporas
}

\author{
Ayasha Guerin \\ University of British Columbia, Canada \\ Ayasha.Guerin@ubc.ca
}

\begin{abstract}
In this paper, I bring together the historiography of Indigenous shore whaling on Long Island with narratives of Black diaspora and whale studies to discuss shared routes of migration in the 17th-19th centuries and shared fates under colonial capitalism. Demonstrating how the extractive conquests of colonial settlers shaped the exploitative treatment of whales and the movements of social groups who lived in dependence to them, I build on Black feminists' theoretical work and methodologies to look for interspecies, trans-oceanic navigations of survival. In doing so, I demonstrate how intimate relations between whales and whalers were shaped by processes of colonization, coastal displacement, and by conditions of indebtedness, enslavement, and fugitivity. I argue the importance of recognizing whales as mammalian kin, caught in the same net of colonial capitalist settlement and resource extraction as their hunters. Finally, inspired by the metaphor of echolocation, a method of listening which helps whales to navigate oceans, I suggest that we might listen for the socio-ecological reverberations of historic whaling diasporas to learn from emergent strategies of survival.
\end{abstract}

Keywords: Black diaspora, interspecies, colonization, Long Island, New York

https://doi.org/10.24043/isj.160 • Received May 2020, accepted March 2021

(C) Island Studies Journal, 2021

\section{Introduction}

This paper begins with acknowledgement of the coastal Algonquian people and their unceded territories on Long Island, New York, and their changing relationship to whales under colonial capitalist policies.

Demonstrating how extractive conquests of Long Island settlers have shaped the exploitative treatment of whales and the movements of racialized social groups who lived in dependence to them, this paper takes up Black feminist methodologies to look for interspecies, trans-oceanic navigations of survival. In showing how intimate relations between whales and whalers were shaped by processes of colonization, coastal displacement, and by conditions of indebtedness, enslavement, and fugitivity, I reveal the entangled fates of species under colonial capitalism and the value of cultivating mammalian kinship for our shared survival.

In the mid- $17^{\text {th }}$ century, Long Island's inhabitants were primarily Indigenous: the Canarsies, Rockaways, Merricks, Massapequas, Matinecocks, Nissaquogues, Secatogues, Unkechaug, Corchaugs, Setauket, Shinnecock, and Mantaukett peoples. The decades that 
followed saw the establishment of a number of English whaling settlements, including East Hampton and South Hampton on the island's eastern end. Soon after British settlement, the sacred Indigenous practice of harvesting drift whales on the shoreline was transformed into a trans-oceanic hunting enterprise that profited white settlers and decimated global whale populations.

Whales are nomadic creatures, the largest animals on land or in the sea. Stretching up to 16.8 meters long and weighing up to 70 tons, the North Atlantic right whale, the species most commonly encountered by Long Islanders, is one of the world's largest animals and one of the most endangered species in the world. The prehistoric population of Atlantic right whales may have been between 15,000-20,000 in number (Laist, 2017), but there are only an estimated 430 right whales left in the world today (Rickard, 2018).

The whale fisheries of the $17^{\text {th }}, 18^{\text {th }}$, and $19^{\text {th }}$ centuries were brutal workplaces. When a whale was sighted from the whaleship, six men packed into a smaller boat and rowed out to lance it with a spear attached to a long rope. Great strength and excellent aim was required to shoot the whale in the lungs, after which the men would hold on to the rope and endure the "Nantucket sleigh ride" - a whale's pulling and thrashing until it drowned on its own blood and sea water. Next, the corpse has to be towed to the ship, and then the process of "rendering the whale" on board began: stripping the skin from the flesh, cutting it into pieces called "bible leaves," and boiling these in large vats on deck so oil could be extracted from the blubber and stored in barrels. This extract lit streetlamps, lighthouses, and interiors, propelling the Industrial Revolution until the discovery of petroleum. Drilling into the brains of sperm whales also produced spermaceti, a highly-prized waxy substance that was used to make the world's best candles (which produced a clear flame and no smoke), while ambergris was extracted from sperm whale intestines and used for perfume. Baleen, or "whale bone," was also cut from whale mouths and used in various household items in the American colonies, including corsets, umbrellas, and other petroleum-based products today.

For over two hundred years of coastal, colonial settlement, New England served as epicenter of the whaling industry. From the $17^{\text {th }}-19^{\text {th }}$ centuries, whaling work brought Indigenous New Yorkers into relationships with European and African whalers. By the $19^{\text {th }}$ century, American whaling voyages stretched several years across the Atlantic and Pacific oceans, their risky pursuits accelerated to satiate the desires of a globalizing world hooked on oil. But whales were not passive actors - they fought back and took human casualties with them. Whales are also very intelligent; they move when heavily attacked in one area. Marine biologists believe that whales communicate with one another through a process of echolocation: active sonar which registers to the human ear as a variety of clicking sounds. As whaling was industrialized, whales responded using echolocation's clicking codes to help them sense and register large moving targets and danger ahead, and to develop new routes of navigation. The farther the fisheries had to travel from local shores to find whales to kill, the more dangerous the journeys were for whalers.

While many whalers were of European descent, this article centers the lives of Black and Indigenous people and their relationships with whales to analyze how colonial impositions of racial differences have instigated new assemblages of oceanic social life. The number of Black whalers in the industry grew with enslaved Africans, and by the hire of free Black fugitives and recruitment of African islanders from Cape Verde and other colonial ports near hunting grounds. As skilled hunters, swimmers, and navigators, Indigenous and Black 
people were disproportionately represented in New England's early whaling ventures, but their opportunities for advancement were compromised by the introduction of racially discriminatory laws and practices that trapped them into spirals of debt while whale populations were depleted.

In addition to Long Island, the islands of Nantucket, Martha's Vineyard, and New Bedford (of coastal Massachusetts) were where many company owners lived and the first crews of the American industry's whalemen were assembled. Historians Starbuck (1878), Farr (1983), Vickers (1985), and Busch (1994) have all written on New England's multiracial whaling industries and their global reach, while historians Shoemaker (2015) and Strong (2018) have specifically researched the experience of Native American whalers. On the experience of Black mariners who navigated the oceans, we can look to the work of Malloy (1990), Scott (1991), Reilly (1993), Bolster (1998), Foy (2006), Pybus (2007), and Morgan (2018).

I build upon their historical research, employing an ethical lens with which to understand the relations of interspecies bodies in the space of the whaling industry. In Men and Whales, Ellis (1991, p. 1) writes that:

It is only through the lens of hindsight that the whaleman's job becomes malicious or cruel [...] Oil was needed for light and lubrication; baleen was needed for skirt hoops and corset stays. That whales had to die to provide these things is a fact of seventeenth-, eighteenth-, and nineteenth-century life.

While chasing whales for oil was considered a necessary violence to keep up modern standards of living, many laboring men subscribed to the errant, gory life at sea because their prospects on land were even less hospitable. Liberal humanism did not serve Indigenous and Black whalers nor whales, as the industry offered low-grade pay with high risk of danger for both species. The floating slaughterhouses brought power and privilege to New York's mercantile class, while often trapping whalers in systems of coastal displacement and debt peonage. Juridical constructions of race shaped a labor system that displaced and pushed Indigenous and Black people to new arrangements at sea. Here, the unsustainable logic of extraction that exhausted whale populations was also extended to whalers, who accrued large debts in times of unsuccessful hunts. Reading the social lives of whalemen against ecological studies of whales, I seek to contribute a more-than-human story of this extractive history, and to connect the disorder of colonial capitalism to the endangerment of whale life and the condition of the errant and indebted whaler.

Adding to island studies scholarship by Hayward (2012) and others who encourage a focus on the aquapelagic relations in oceanic space between islands, I argue that whaling grounds represent an important "aquepelago" navigated by Indigenous and Black men for three centuries, where the historical reverberations of slavery, colonization, and displacement shaped nomadic identity formation. The 'whaling aquapelago' presents an important record of interracial and interspecies relations in an overlooked extractive history shaped by strategies of migration as survival, and trans-oceanic navigations towards freedom. 


\section{Methodology}

Taking encouragement from Pugh's (2016, p. 1042) suggestion that islands, oceans, and ships should be conceptualized in relation to one another, "because they are often inextricably interwoven into complex, multifaceted and shifting arrays of relations and assemblages," this paper follows the "relational turn" and "oceanic turn" in island studies, focusing on movements between ports and hunting grounds of what I term the whaling aquapelago. The term "aquapelago" was proposed by Phillip Hayward (2012) as a corrective to the strong terrestrial focus within the field of island studies and describes regions in which aquatic spaces play a vital constitutive role in social and cultural life. Katherine McKittrick (2016, p. 3) has encouraged the creation of methodologies of care that do more than account for anti-black violence, but "notice" Black Atlantic livingness. The whaling aquapelago is spatially, and theoretically, a recognition of the assemblage of docks, ships, ocean currents, and shorelines that Black and Indigenous whalers precariously navigated from the $17^{\text {th }}-19^{\text {th }}$ centuries to survive their circumstances. I bring McKittrick's Black geographical reading practice to this socio-spatial analytic from island studies to ask: how are extractive relationships at sea interconnected with histories of Indigenous and Black displacement from land?

Thinking with/in the oceanic is an approach that Black Studies and Black feminists have used for some time. We understand the Ocean is the primary site of the disaster of transAtlantic slavery, responsible for patterns of diaspora, dispersal, and the ongoing resounding sense and awareness of precarity of being Black. Christina Sharpe (2016) has offered "wake work" as an oceanic methodology for continuing to imagine new ways of survival "in the wake" of slavery. She suggests that one might approach Black being in the wake "as a consciousness" (Sharpe, 2016, p. 13). Sharpe's work influences my treatment of the aquapelago, offering another layer of "noticing" the intimacies of survival at sea in the whaling industry, for an expanded consciousness of the effects of slavery on our world today. Tiffany Lethabo King's (2019) The Black Shoals offers another oceanic metaphor for where Black Studies connects land and water, and a geographical site where Black Studies engages Native Studies on ethical terms. Her "shoals" (King, 2019, p. 28) refers to a metaphorical place of juncture - between the slave ship and Indigenous land - an analytical site that reveals the ways that some aspects of Black and Indigenous life have always already been a site of co-constitution.

The Black and Native scholar and poet Alexis Pauline Gumbs (2020, p. 7), in her book Undrowned, argues the value of "listening to marine mammals, specifically, as a form of life that has much to teach us about the vulnerability, collaboration, and adaptation we need in order to be with change at this time." This paper takes up this Black feminist act of listening, too, which is, as Gumbs (2020, p. 15) writes, "a transformative and revolutionary resource that requires quieting down and tuning in." For me, this process has involved studying the record of Black and Indigenous life at sea alongside the descriptions of ecologists and naturalists who have observed whale behavior. Like Gumbs, who describes a process of submitting to the mentorship of marine mammals, this paper argues that we might consider whales mammalian kin, acknowledging that we have historically shared a positionality as exploited. By identifying with these mammals, rather than to study them as bygone resources of flesh and power, opens up a reading of relation that requires us to deconstruct how codes of race have structured differential human experience even as we decenter the category of the human. 
In her canonical Black feminist text, Mama's Baby, Papa's Maybe: An American Grammar Book, Hortense Spillers (1987) discusses how African American experience of gender and family has been shaped by the historical diasporic enterprise of enslavement. Spillers (1987, p. 75) argues that, as captive persons were forced into patterns of dispersal, they developed "certain ethical and sentimental features that tied her and him, across the landscape to others [...] of the same and different blood, in a common fabric of memory and inspiration." Recognizing that, under conditions of enslavement and their aftereffects, genetic relation has not always produced the psychological bonding expected by normative (white) expectations of "family" for Black people, Spillers (1987, p. 76) asks, "Could we say, then, that the feeling of kinship is not inevitable? That it describes a relationship that appears 'natural,' but must be cultivated under actual material conditions?" While genetic reproduction was never on the table, certainly history has shown that feelings of kinship between humans and whales is not inevitable either. Still, I argue that by tracing the material conditions of the industry within the context of colonial capitalist expansion, there emerges another way of relation that would serve everyone's survival. In turn, I query the im/possibilities of kinship with marine mammals though a study of race-relations at sea and shoreline.

I build on Spillers' (1987, p. 67) distinction between the body and flesh as "the central one between captive and liberated subject-positions." She reminds us that enslaved subjects were taken into account as quantities of flesh - not as bodies of individuals - before they became valued on land. The Black men I write about in this paper are returning to the sea under the pressure of these events. But while it was flesh which served the primary narrative of their arrival, it was flesh (of whales) that they returned to sea to find to recover their own narratives of survival. Such fleshy intimacies are punctuated by the fact that whaling ships and slave ships shared the same oceanic routes, and that some whaling ships became slave ships when the whales were gone.

The boundary drawn between the human and animal matters, especially for those whose identification sits on the border. Sylvia Wynter's (2001) work identifies how the white colonial subject only encounters herself or himself of being human in relation to the deficiency of the Black and Indigenous subject. She critiques the category of the human in Western subjectivity, where the invention of Man has served the political subject of the state. Wynter encourages that we craft other genres of the human, or other codes for what it means to be human, within the history of species (Wynter, 2001). If, we understand humanity as a relational ontological totality, where racialization is an assemblage of processes that establish certain groups' aberrations from the Western ethnoclass of Man, then Wynter's work also serves as a warning to animal studies discourses, which want to overcome the hierarchy of the human over other species. As Alexander Wehiley (2014, p. 10) has written, Wynter reminds us against falling into the trap of "presuming we have entered a stage in human development where all subjects have been granted equal access of western humanity."

My analysis is informed by these methodologies of distinction and study as I consider how colonialism and conquest racialization has shaped the ecological entanglements of interspecies survival in whaling histories. In this paper, "Black" is a racial category that includes Indigenous descendants, as many Indigenous and free Black people intermarried over the centuries of work together in the New England whaling industry. Bringing together an interdisciplinary and interspecies reading of displacement - of whales from their natural habitats (aka hunting grounds) and of Black and Indigenous people from their land into the 
whaling industry - I offer an interspecies reading of racial capitalism in the condition of endangerment for whales and the errant and indebted whaler.

\section{Race and aquapelagic analysis}

The rise and fall of New England's whaling history began on Long Island's littoral. If you were to walk across the island in the mid- $17^{\text {th }}$ century, starting in the land that would later be named Brooklyn and ending in Montauk, you would have crossed several Indian nations over three or four days. A few decades later, you would have encountered a growing number of English whaling settlements, including East Hampton and South Hampton, on the island's eastern end. During winter months, when seas were high, drift whales often washed ashore. For the coastal Unkechaug, Montaukett, and Shinnecock peoples of Long Island, a beached whale was cause for a celebration. Using coastal flint fashioned into knives, Indigenous people cut the meat from whale bones and distributed it for eating among their community in a ceremonial process.

Laist (2017) suggests that the Indigenous people of Long Island were skilled butcherers of the large creatures that washed up on their shores, but that it is unlikely that they hunted large whales at sea before the arrival of the English colonists. The unique geography of the shoals, sandbanks, and barrier islands along Long Island's coast aided the practice of shore whaling, as whales followed schools of fish, unknowingly, into shallow waters. Lipman's (2015, p. 6) study of the "Saltwater Frontier" reminds us that the colonization of New York was a process that happened at sea as well as on soil. Early deeds between the English and the Montaukett for the purchase of coastal lands on eastern Long Island indicate salvaging whale parts on the beach continued as an important Native custom after the colonist's arrival. Indigenous leaders negotiated deeds with Europeans over the coastal land and tidal flats, which ensured the retention their own use of the shoreline, prompting centuries of disputes over who assumed the right to harvest drift whales on this "property" (Strong, 2018). For example, in 1648, the Montaukett people negotiated their right to continue to "have the fynns and tayles of all such whales as shall be cast up" (Edwards, 1932/2018, p. 194) in present day East Hampton. Ten years later, a Southampton deed belonging to Lion Gardiner stipulated, "whales cast upon this beach shall belong to me and to other Indians within these bounds" (Fragments of the Gardiner Deed, ca. 1658).

Records of Unkechaug complaints that the English settlers had taken their fish after they had driven them upon their beaches suggest that Indigenous people on Long island might have even had a special whaling technique that guided the animals onto the shore, much like schools of fish (O'Callaghan \& Fernow, 1883, pp. 720). But soon this custom, as well as the salvaging of whale parts at the shoreline, was privatized as colonial settlement brought a new era of whaling that actively hunted the mammals in deep waters. In 1664, the Dukes Laws announced by New York's first colonial Governor, Richard Nicolls, required one gallon of whale oil for every sixteen produced from drift whales to be provided to the Crown, while any whales killed at sea were exempt from the tax (Starbuck, 1878, pp. 26-27). This pushed whaling from the shore into the sea, and when Governor Thomas Dongan reauthorized the tax exemption in the 1680s, it further encouraging the practice of offshore hunting.

The first American whaling expeditions left from South Hampton, Long Island for one or two weeks at a time, but didn't stray too far from the coast, with crew members camping 
on the shore at night (Howell, 1866, p. 183). As Lipman (2015, pp. 222-235) argues, shore whaling was not a colonial invention, but a "joint creation" of two cultures, as few Englishmen had the skills necessary to hunt whales in open boats, nor were they willing to venture out beyond the surf during the cold winter months. European efforts failed to sustain shore whaling enterprise until they turned to the young men from the Unkechaug, Shinnencock, and Montaukett villages (Laist, 2017, p. 182). While whaling work intimidated new settlers, Indigenous people were accustomed to navigating small boats on the open waters and were also skilled spear hunters (Strong, 2018, p. 78). Whaling Masters, men and women with wealth to invest in sea-going equipment, hired Indigenous people and forced slaves to labor for them at sea.

The migration of North Atlantic right whales soon influenced the shore whaling schedules of Long Islanders. The hunting season spanned the coldest months of the year from November through April, when Right whales swam along the Atlantic shoreline. Pregnant whales swam along Long Island beaches from November and down a southern migratory corridor to give birth in warmer waters along the coast of Florida and Georgia (Reeves et al., 1999; see also Kraus \& Rolland, 2007, pp. 19--21; Baumgartner et al., 2007). While right whales are nomadic (they do not swim on regular paths or travel in large groups), this cyclical pattern of movement along the shores made female whales more vulnerable to hunters on Long Island (Strong, 2018, p. 7).

Killed on the open water, a dead whale floated, but whaling crew had to move quickly to process the meat in order to extract whale oil, as the carcass had to be butchered before the sharks arrived. In the harsh winter months, it was possible to die in just a few minutes from hypothermia if one fell overboard. As the fisheries strayed further from the coast in pursuit of dwindling whale populations, whalers boiled cuts of "flensed" blubber, cut from whale flesh, in giant pots on the wooden decks (Strong, 2018, p. 58).

Early labor contracts with Indigenous men were based on a colonial barter system wherein goods were exchanged for services. As demand for labor grew while communities suffered the onslaught of the smallpox disease, settlers reliant on falling numbers of an Indigenous workforce passed laws to limit their bargaining power. In 1672, New York's second Governor, Francis Lovelace, wrote a law requiring that "whosoever shall Hire an Indian to go a-whaling, shall not give him for his Hire above one Trucking Cloath Coat, for each whale hee and his Company shall Kill, or halfe the Blubber without the Whale Bone, under a Penalty therein exprest" (Minutes of the Executive Council of the Province of New York, Vol. 2, 1668-1672, as cited in Starbuck, 1878, p. 11). Paying Indigenous whalers in cuts of blubber removed the obligation to pay for their labor during an unsuccessful whaling season. It also motivated them to kill more whales, quickly. Whalers would increasingly be assigned lays, or shares, of a crew's total earnings from the hunt, becoming the standard for whalers well into the mid- $19^{\text {th }}$ century and the end of the whaling era.

The refusal of Indigenous people to submit to European whaling contracts that did not pay them a fair wage is well documented by John Strong, whose scholarship explores the political economy of early Long Island whaling settlements. Contracts required men to go whaling several seasons with the same owner, but often Native workers refused to submit to their employers' control, breaking contractual agreements which did not benefit them (Strong, 2018, p. 118; see also O'Callaghan \& Fernow, 1883 pp. 756-757 ). Most exploitative was the whaling industry's credit system. Indigenous sailors bought their day-to-day needs 
from the whaling companies on credit until they were paid for their work, which was sometimes years after setting sail. At sea, they bought clothes and up-priced alcohol, which often brought them into debt when they arrived back home. Two centuries later, this pattern of debt accumulation persisted. Meanwhile, many indebted whalers were forced to sell their debt to farmers, for whom they would then work as indentured servants. On Long Island, when Indigenous people were unable to come up with payments, they had to forfeit tribal land to the court. This introduction of debt was often the means of Native land dispossession on Long Island. As Strong (2018, p. 125) traces, "it is not too much of an exaggeration to say that the use of Indian indebtedness to obtain land was successful, and perhaps more widespread, than the use of alcohol or fraud."

After just twenty years, the local right whales of Long Island's coastal waters were exploited to endangerment, while many Indigenous tribes had been driven from the coast into work at sea and into debt. Indigenous freedoms and land rights became intertwined with the process of hunting whales, and a subsistence and spiritual practice was hijacked towards unsustainable capitalist accumulation. Colonists tried to introduce an ideological system of race that prescribed cultural narratives $($ White $=$ civilized; Native $=$ savage) to exert political control and amass wealth by appropriating land, resources, and labor.

As a historian of Indigenous whalemen, Nancy Shoemaker (2015, p. 9) argues, "although the whaling industry was implicated in the processes of capitalism and colonization that brought hardship to New England's Native population, it simultaneously offered coastal Native communities the best means to survive these changes." The cosmopolitan identities that Indigenous New Yorkers developed from their travels abroad contradicted the assumptions that European colonists held about their "primitive" nature, as did the wealth and power that some Native leaders of the whaling industry were able to gain from successful journeys. After all, it was Native knowledge that had propelled the industry into the sea. It was the colonialists' capitalist culture that would prove the hunt unsustainable. As an important stratum of the global workforce, Indigenous workers in the New England whale fisheries were both pioneers of, and fell prey to, the extractive economy that lit up the cities of a growing modern world. Over the next two centuries, through this new relationship with whales, Indigenous Long Islanders would travel the world, mastering navigation and accumulating languages and knowledge about other cultures. In some cases, they would resettle themselves, on islands far from their own home.

Exemplifying the intersectional histories of species and racial displacement in the Island's colonization, the migrations of whales away from Long Island mirrored that of many of the men who came to hunt them. By the mid-1700s, New England's industry men had considered the Atlantic to be "fished out" of whales, but sightings off the coast of West Africa spurred a new era of trans-Atlantic hunts. In this period, whalers began sharing routes with slave ships, as the African coast became a space for both hunting whales and recruiting crew. When thousands of Black people in New York gained their freedom in the early $19^{\text {th }}$ century, they sought waged work in the whaling industry, which was one of the few employment options available to them.

Because the workforce of Indigenous whaling communities on Long Island and the New England whaling archipelago intermarried with Black workers, some of them fugitive slaves, several prominent whale industry men in the $18^{\text {th }}$ and $19^{\text {th }}$ centuries were of mixed African and Native descent. Records of race in the New England fisheries are not always 
explicit. A sample of men from crew lists from the $19^{\text {th }}$ century who listed their place of birth as Sag Harbor, Long Island, for example, recorded over forty "dark," "Black," "negro," or copper" men. Sailors were only occasionally listed with more explicit attention to racial categories, like "negro," "mulatto," "Indian," or "colored," while hair was noted as "brown," "dark," "Black," "light," or "wooly" (New Bedford Whaling Museum, 2020). Living, working, and raising families together, because they were denied the freedom to mix as equals with the British-American majority, they came to be regarded as a single, undifferentiated, subordinate caste: "seamen of color." As Vickers (1985, p. 290) writes of the interracial whaling island communities, "their common status as outsiders served continually to blur the distinctions among them and to draw the different groups together." The whale fisheries of New England provided opportunities for fugitive enslaved people on the run to blend into a free interracial society. Crispus Attucks (an American stevedore of African and Native American descent, widely regarded as the first American killed in the American Revolution) and Prince Boston (the first enslaved person in Massachusetts to successfully sue for his freedom and receive back wages for his time spent on a whaleship) are two such runaways who sought out whaling work in their pathways to freedom. Prince Boston's nephew Absalom Boston would become the first whaleship captain known to employ an all-Black crew (Farr, 1983, p. 160).

One reason that so many Black people lived at sea is because of the security of Seamen's Protection Certificates. Beginning in 1796, the federal government issued Seamen's Protection Certificates to free, working seamen, which defined them as citizens. While on land they would not be recognized as U.S. citizens until 72 years later (with the passing of the Fourteenth Amendment in 1868), Seamen's Protection Certificates positioned, in writing at least, Black man's status as something equal to his white counterpart. These papers were often faked or lent to Black men to escape slavery in southern ports. On ships, punishment doled out from captains mirrored that on the plantation, with floggings being regular occurrences. Interestingly, Morgan (2018) argues that letters penned by African American sailors often avoided the metaphor of enslavement so popular among white sailors; rather, they proclaimed their citizenship. What can we make of the fact that Black men had to leave their terrestrial lives behind in order to be recognized as citizens?

For those born into slavery, the pursuit of freedom required a trade of their own capital value. One way to pay one's freedom could have been to take work on the whaleship. Other enslaved people "stole themselves" and moved to New York City, where the largest free Black community of the North was formed. Even though slave code enacted at the early $18^{\text {th }}$ century made it illegal for a ship captain to assist runaways (signaling that many enslaved people utilized maritime skills to facilitate permanent escape from enslavement), New York's maritime industry was a portal to freedom for fugitives and runaways throughout the $18^{\text {th }}$ and into the $19^{\text {th }}$ century. Foy $(2006$, p. 77$)$ explains:

fugitives were largely assisted in reaching their goal of freedom by sea captains who were more concerned with being able to leave port as soon as possible with a full crew than they were with legal niceties that said they should not employ another man's bondsman. 
Such conditions signal the importance of the ship — the whale fishery — as a place where free Black identities were forged.

Work on whale fisheries afforded economic opportunity and freedoms that existed in few other industries. There were opportunities to advance one's position in the crew, plus sailors could transport goods from the foreign ports they visited to sell for profit at others to augment their pay, or to gift to family at home ports. Whaling might have also offered the most social equality and equal pay to whites at sea, a feeling of "being in the same boat" with fellow crewmen, even if that boat was dangerous. As historians Bolster (1998), Foy (2006), and Shoemaker (2015) have suggested, gender also informed relations aboard ship by transcending the distances created by rank, race, nationality, and culture to bind whalemen around a common masculine identity.

At the turn of the $19^{\text {th }}$ century, Long Island fisheries turned to fitting out sloops for longer voyages to the Pacific in search of deep-water species, such as sperm whales and bowhead whales, but these expeditions required more dangerous routes that stretched around Cape Horn to the Pacific and Arctic Oceans. The observations in American whaling logbooks of sperm, right, bowhead, grey, and humpback whale sightings provide information on $19^{\text {th }}$ century fisheries distribution patterns that is available in no other way. These records trace migrations between home ports and frequently used ports, and to popular whaling regions known as "whaling grounds" (Smith et al., 2012). A fishery leaving from New York might have explored the Azores and Cape Verde islands off the coast of West Africa, stopped south at St. Helena (an island midway between the African and American continents), then moved on to Argentina and around Cape Horn to ports in Chile and Peru before reaching the Pacific Islands (Shoemaker, 2015, pp. 16--17). Whalers stopped at many coastal and island ports during their voyages to rest, but also to obtain provisions, repair vessels, offload whale products, and recruit inexperienced sailors from these shores to join their crews.

Between 1820-1860, whaling was a booming industry, but it offered the lowest-grade and most poorly paid of maritime work and was often taken out of desperation. Meanwhile, whales were learning, listening, and resisting. One huge sperm whale in particular was known as a fighter, and is responsible for inspiring Herman Melville's 1851 novel, Moby-Dick. Even though it was harpooned many times, this old white whale refused to die easily. It fought back, attacking boats and snapping them like twigs with its tail. When Mocha Dick (the whale's true nickname, after a Chilean island) was finally killed, 19 old irons were found embedded in its body (Dolin, 2008, p. 113).

While most whales were passive, playful, and adapting their routes to avoid their hunters, narratives like Melville's branded whales as terrors of the sea, bent on mayhem. Melville drew inspiration for his novel from his own experiences working on whaling ships and from speaking with whalers about their encounters with whales, one of which was the son of first mate Owen Chase of the Essex tragedy. The cautionary tale of the Essex, a ship whose crew experienced destruction by Mocha Dick in the South Pacific whaling grounds and, rather than stopping at an island where they believed Indigenous cannibals might live, instead drifted until they became cannibals themselves, reflects a telling irony that their fear of the racialized unknown is what ultimately harms them, not the whale. Those whalers who sought the flesh of the whale were unmoored by narratives that their own might be hunted on land.

As whales navigated new routes to new feeding grounds, whalers were left drifting dependently. Crossing the Atlantic took six weeks minimum, and the more dangerous, 
worse-paying whaling tours to the Pacific often lasted for months, even years. If sailors survived their tours, there were opportunities to earn money and move up in the trade, but often these men chose instead to jump ship up while visiting a foreign harbor. A Black whaler might have preferred a voyage that brought them overseas rather than to take coastal work that sailed to the southern slave states, where he faced the possibility of being imprisoned if he disembarked the ship. From the 1830s, Southern coastal states passed laws to imprison free Black seamen in port towns from Charleston to New Orleans "as security against the possible importation of seditious ideas about slavery" (Foner and Lewis, 1978, p. 190).

For those caught in the debts of the industry, drifting from port to port and hoping to strike luck with a whale — or jumping ship when stopped at an island for provisions - was their only means of survival. Designed to avoid paying whalers for an unsuccessful journey, the system for earnings on whaleships protected the shipowner's profits, as each crew member only received a percentage of the total profit hauled home (Bolster, 1998, p. 161). The rare successful trip was known as a "greasy voyage" and ones that cleared expenses were known as a "saving voyage" (Federal Writers' Project of the Works Progress Administration of Massachusetts [WPA], 1938, p. 17). As the $19^{\text {th }}$ century progressed, more experienced sailors knew to avoid the difficult and lengthy mission of whaling work if they could, so whaling merchants often hired inexperienced "greenhorns," a name for new sailors who accepted low wages out of naïveté and limited options. On these journeys where whale life was not valued, neither was the life of whalers.

Those who took on the difficult work often found themselves in a slippery system of maritime debt peonage. Shipping agents and merchants developed a variety of schemes to cheat whalemen, as Farr (1983, p. 162) writes, “Inflated charges for a whalemen's initial outfit or items of clothing and tobacco purchased from the ship's 'slop chest' often left the tar with nothing at the end of a voyage." It was possible for whalers to end voyages two or three years in debt to the ship's owners. A seamen's initial indebtedness could be $\$ 125$ from clothes and commission paid to the land shark agent, while only $\$ 225$ was the average lay after a successful two-year voyage (WPA, 1938, p. 23). Many men who passed a lifetime at sea invested their savings, as well as their family's and friends', only to meet disaster. The writers of the Works Progress Administration project entitled Whaling Masters (WPA, 1983, p. 18) suggest that "Few industries have ever been such a gamble between enormous profits and financial ruin."

In 1820, New England's whalers sighted the Arctic, and most fisheries began fitting out sloops for long journeys to hunt whales there. The U.S. whaling fleet peaked in 1846, with 735 ships out of 900 globally (Dolin, 2008, p. 238). By this point, sperm and right whales had been hunted to the brink of extinction in Atlantic waters from the Americas to Africa. In 1853 alone, 8,000 whales were slaughtered in the New England fisheries (Applebome, 2008). The years 1859-1872, however, saw the decline of whaling due to several causes: civil war, hostile Arctic conditions, and, most importantly, the discovery of petroleum. As many whaling merchants faced the reality of bankruptcy, whaleships were being sold or transferred out of the industry by the start of the Civil War. Evading federal law enforcement, which prohibited the dispatching of slave ships from American ports, slave companies sometimes used whaling shipping agents as fronts.

On Long Island, several American whaleships are recorded to have become involved in the Atlantic slave trade. Reilly (1993) is one of the very few to have traced this history. His research shows that the vessels Thomas Watson, Atlantic, Montauk, Manual Ortez, and Iowa 
delivered (or attempted to deliver) enslaved Africans to Cuba between 1859 and 1861, smuggling between 500 and 900 enslaved people each (Reilly, 1993, pp. 188-189). On Long Island, the whaling vessels Romulus and Augusta were also outfitted in Cold Spring and Greenport harbors for the slave trade during the same period; the latter was seized and condemned twice in 1861. Whaleships were useful to slave traders because their large holds could fit hundreds of enslaved people and the pots used for extracting oil from blubber could be adapted to feed large numbers of enslaved people in the hold. Reilly (1993, p. 180) writes, "the combination of functional adaptability and American registration papers made whaleships not only viable but also desirable slave ships." While financial disaster in the whaling fisheries drew some whalers into the slave trade voluntarily, it is possible that others were manipulated onto ships believing they were going whaling, only realizing that they had been duped by captains after they had cleared port.

The men entering the whaling industry in New York by mid-19 ${ }^{\text {th }}$ century were increasingly European immigrants, but there were also Black and Indigenous men who found themselves on these new dangerous routes. As Shoemaker's (2015, pp. 12-14) research traces, throughout the $19^{\text {th }}$ century, the majority of Native men living near the southern New England coast went on at least one whaling voyage in their lifetime, and many were career whalemen who spent 20 to 30 years at sea. Men from small islands with few opportunities were targeted for recruitment into the New England fisheries in the $19^{\text {th }}$ century. The Caribbean island of Bequia, Saint Vincent, was a popular recruiting place and developed as a central node of the whaling aquapelago, known for the processing of humpback whales (Fielding, 2018, p. 242). African Cape Verdeans (sometimes referred to as "Portuguese") made up $20 \%$ of whaling crews by the 1860 s, and by the 1880 s this number was $35 \%$. As Busch (1994, p. 42) writes, "Cape Verdeans came from an island chain poorly endowed in resources by nature and subject to killing famines and droughts." Because they were desperate to escape these environmental conditions, the men of these islands "were eager to serve on American whaling and sealing vessels, usually for the lowest pay rates going, in order at the end of the voyage to be somewhere else- preferably America" (Busch, 1994, p. 42).

Cape Verdeans used the fisheries to migrate. They formed a large community in the New Bedford whaling port and in numerous others across the Atlantic and Pacific whaling aquapelago, with many using the fisheries to sail to and disembark in San Francisco at the height of the California Gold Rush in the 1850s (Bertão, 2006). In the period between 1820 and 1880, as many as 8,000 Cape Verdean whalers settled in Hawai'i- (Sharma, 2019), where there were also a few Native American beachcombers living out their lives after jumping ship during a whaling journey. In Fiji and New Zealand, where racial categories emerged directly from the process of European colonization, Native American men - Native to the Americas only - were newly foreigners (Shoemaker, 2015, p. 8, pp. 129-144).

Some Black and Indigenous men chose to abandon their lay and bet their hand at life in Polynesia, while others returned to New England. As Sharma (2019, p. 124) notes, in the $19^{\text {th }}$ century, the Kingdom of Hawai' $i$ was not organized on the basis of race, and to Black whalers, for whom the sea was a refuge, "the islands became an extension of that refuge - a place without slave codes and that presented openings unavailable in the US, including the freedom to be oneself." The irony that men in New York might have boarded a slave ship disguised as Hawai'i-bound fishery in pursuit of freedom is especially wicked given that racial categories and blood-quantum reasoning would meanwhile be used to enable widespread 
displacement of Indigenous people from their coastal lands - from the Pacific Islands, to Long Island, New York, and throughout colonized regions.

Nearly three centuries after the first encounter between the Montaukett tribe and English settlers on Long Island, a bill was introduced by Assemblyman John. J. O' Connor in 1922 seeking $\$ 300,000$ compensation for the Montaukett people. This bill represented a "continuation of attempts made by Indian decedents to obtain money for lands of the aborigines sold in 1649-80" (Brooklyn Daily Eagle, 1922, p. 12), and followed a series of lawsuits brought by the Montauk Tribe against the Benson family, the landholders of the Montaukett "Indian Fields". While the initial land claims (Montauk Tribe of Indians $v$. Long Island R.R. Co. in 1898 and Johnson v. Long Island R.R. Co. in 1899) were dismissed on the basis that "the tribe had no standing in court," (Pharoah v. Benson, 1910) in 1906 the Legislature passed an "enabling act" that gave the Montaukett tribe the statutory right to sue, prompting the commencement of a third action, Pharaoh $v$. Benson. This series of suits proposed that when Mountauketts wrote the deed in 1661 to the proprietors of East Hampton, they received a counterbond wherein it was agreed that "the Indians, their heirs and successors should, forever, have the right to occupy said land" (Pharaoh v. Benson, 1906, p. 433). As I have referenced, the colonial political economy of East Hampton relied on systems of debt to effectively displace and dispossess Indigenous Long Islanders of their land, despite such bonds.

In 1910, after searching early records, Justice Abel E. Blackmar found in favor of the defendants, ruling that the Governor Dongan patent, which gave settlers rights to purchase the land in the $17^{\text {th }}$ century, was lawful. But there was another reason he dismissed the case: in his concluding remarks, Blackmar declared, "I hold that the purchase [by Mr. Benson] was a lawful act and there is no consideration of justice which makes me loath to find there is no longer a tribe of Montauk Indians" (Pharaoh v. Benson, 1910). As the Brooklyn Daily Eagle (1922) put it, "the gist of the Blackmar decision is that the tribe, by intermarriage with Negroes, has disintegrated and has been absorbed into the mass of present-day citizens." The newspaper article, published in 1922, notes that in these communities, "there is now a very large mixture of Negro blood, both in the survivors of the original Indians and the remnants of both the Montauks and Shinnecocks" ("Montauk Tribe Extinct", 1922). The free Black communities of Freetown, East Hampton, and Eastville (Sag Harbor) had become more interracial when Indigenous families were removed from the settlement called Indian Field after Mr. Benson's purchase of their land in 1879. Mrs. Florence P. Pharaoh, who names herself as Queen of the Montauk tribe, responded to the Brooklyn Daily Eagle from Sag Harbor in 1922:

I wish to correct an Error in the article which you published Feb 17, captioned "Montauk Tribe Extinct." The article stated that the present queen, widow of King Wyandanch is a full-blooded negro and a daughter of James Van Houten, a negro musician, who was born in a slave state and settled in Sag Harbor after Civil War. I am not a full-blooded negro and my father was not born in a slave state. His place of birth was Sag Harbor, and my dear old mother was a direct descendent of the Montauk tribe of Indians. (p. 12) 
Queen Florence's assertion of both Black and Native identity in her response to the Brooklyn Daily Eagle reminds us of the ways in which the "one drop rule" of Blackness has been used to discredit and dispossess Indigenous people of coastal lands with a "vanishing Indian" narrative. While this paper has sometimes referred to whalers as Black or Indigenous, such testimonies remind us of the possibilities for overlap of the former and latter categories in histories of coastal communities, especially as we might read their presence in the archives, in crew lists, or other physical descriptions. It is important that we continue to acknowledge the erasure of these interrelations and racial overlapping as we consider human interdependencies with one another and with other species like the whale.

King's (2019, p. 10, p. xiii) work encourages study of the various ways that Black politics and Black studies incorporates the struggle against Native genocide into its ethical frame and asks:

What changes are required of normative routes and knowledge systems that consider the ways that Black presence in the Americas casts a shadow on and informs the projects of genocide, settlement, and the remaking of the human under ongoing colonial conquest?

In thinking through the above history of racial enclosure, debt, and displacement in Long Island's early whaling towns against the history of Black and Indigenous racial mixing on Long Island and other whaling industry islands, the importance of Wynter's work on race as a colonial construction emerges through the language of extinction, which is simultaneously used for Black/Indigenous people and mammalian kin. Gumbs holds ancestry from the Shinnecock Indigenous tribe of Long Island. In Undrowned, Gumbs (2020, p. 59) acknowledges that "the same systems of oppression that harm me also harm advanced marine mammals," and asks, "I wonder if responding to violent structures on human migration and systemic displacement of communities of color also requires collaboration beyond species." Writing that "White humanity and its self-actualization require Black and Native death as its condition of possibility," King (2019, p. 21, p. 26) asks how Black people in the Americas can work towards Black and Indigenous peoples' futurity. This, along with the work of Wynter, Spillers, and Gumbs, suggests that we must confront the question: what have we lost in relating to one another through paternal ties rather than in relational interdependence?

Harvesting drift-whales sustainably had been an important littoral honor and Indigenous custom, and communal subsistence whaling was practiced in New England for many centuries before European arrival. But as the trade grew under colonial capitalist policies, Indigenous people were displaced from coastal homes and subsumed into an extractive relationship with the species in deep water. What Indigenous and Black men gained in freedoms from the hunt of the whale wasn't sustainable. As the whales of the North Atlantic became endangered, so too did the lives of whalers. The further they had to travel from shore to find whales, the more dangerous the journey for whalers, and Black and Indigenous people suffered disproportionately to white settlers, who had more labor opportunities on land.

During the antebellum period, whalers' pay deteriorated more substantially in New York ports and suffered drastically when petroleum began to supplant whale oil in all its uses. The discovery of petroleum made whale products less valuable and the arduous sea hunts less profitable. This shift thrust many whalers out of work and into the debt accrued at sea. 
Maritime labor markets routinely excluded men of color during financial slumps and, as the $19^{\text {th }}$ century progressed and more white immigrants entered the business, fewer and fewer opportunities to rise up in the trade were allowed to Black men (Busch, 1994). As the value of whale oil declined, so too did the importance of whales in our cultural memory, and that of whalers, whose navigations of precarious life once powered the lamps of our growing cities.

\section{Conclusion: Echolocation as relation}

Long Island's colonization brought Indigenous whaling activities from the shoreline into trans-oceanic global matrices of power, endangering the North Atlantic right whale and six other whale species, as well as Indigenous recruits from islands across the whaling aquapelago. The exploitative effects of settler colonial conquest can be traced not only on land, but through the routes of those whalers whose livelihoods have been entangled with the nonhuman species in the sea. Rather than placing Black Studies at the center of Colonial Studies discourse, my attention to the historical reverberations of Black and Indigenous whaling diasporas "pulls settler colonial studies off-shore" (King, 2019, p. 19) in productive relation to Black Diasporic thought.

Left at peace, North Atlantic right whales can typically live up to 70 years, but as Indigenous whaling knowledges were harnessed by colonists and transformed into deep sea enterprises, their populations plummeted. By the end of whaling's hay day, it would become clear that the species loss in local waters forewarned of the forces of extractive capitalism on the poorer and racialized social classes hired to exploit them. Seafaring became an extension of the precarious terrestrial existence for Black and Indigenous men, who often shared a precarious life of displacement and migration with the whales that they hunted. And as whales adapted their routes to deeper, colder waters, sailors from Long Island migrated in search of safer social harbors in the whaling aquapelago, some getting as far as Hawai'i. Echolocation emerges as a powerful metaphor for the navigation of these historical memories and their resonance for wayfinding in in the wake of slavery. As an acoustic eye for ocean depths, a mammalian code that resonates as it relates and responds to threatening encounters, echolocation reflects the relational listening practice I have modeled in this paper.

The laws and social practices that pushed men off land and into captivity and work at sea produced Black and Indigenous diasporas of fugitivity; men who ran from farms and plantations to whaling hubs on Long Island and elsewhere. These migrations represent the routes of a littoral society that connected Black and Indigenous struggles and opportunities under colonial capitalism. While they increasingly struggled to sustain livelihoods in the dying maritime industries, the movements of Black and Native whalers within the whaling aquapelago should be understood as constituting important geographies of identity formation. They alert us to the importance of sea skills for Indigenous and Black survival. For those who worked on whaleships, migration was a condition of everyday life, and, for many, hunting whales was a means to navigate the crisis of slavability and displacement on land.

The changing relations between Indigenous and Black whalers and whales over the $17^{\text {th }}$ through $19^{\text {th }}$ centuries reflect the importance of layering post-colonial and ecological perspectives together - and the relationality of Black and Indigenous communities in antiBlack settler colonialism. What emerges is a consciousness that integrates understandings of how species endangerment has been entwined with histories of racial subjection, exploitation, 
and precarity. Long Island is but one case study in a chain of islands of historical whaling routes that suffered the effects of colonial capitalist exploitation. I suggest that we might listen to the movements of historic whaling diasporas to understand trans-oceanic navigation as an emergent strategy of survival. If we listen, we can hear the resonances of this extractive history for contemporary movements across the globe, demanding LANDBACK and reparations. We ought to address the debts owed to the whales of the world, whose slaughter and oil powered Western growth - and to the whalers, whose trans-oceanic labors tell stories of displacement and nomadic identity.

Men no longer drill into the heads of whales for oil, but are still drilling elsewhere, and this extraction continues to endanger sea life and coastal communities. At the century scale and without adaptation, the vast majority of low-lying islands, coasts, and communities face substantial risks. The island and coastal communities of the former whaling industry are the same geographies that face the worst effects of sea level rise, brought on by the fossil fuel industry that replaced them. Researchers say, if whales returned to their pre-commercial whaling numbers, their gigantic breathing would store as much carbon as 110,000 hectares of forest, the size of Rocky Mountain National Park (Pershing et al., 2010). Instead, survived right whales are swimming into new territories for food because of changing sea temperatures. More and more are dying by ship strikes, while birth rates are extremely low (Rickard, 2018). The extractive treatment of natural resources continues to endanger sea life, and us.

Within the field of island studies, there is much discussion about the effects that climate change will have on small island states, and authors like Walshe and Stancioff (2018) have argued for the importance of a longue durée approach to adequately understand and account for local perceptions of climate and climate change. We know that accelerating sea level rise will prove a major impetus of further aquatic interdependencies and littoral diasporas, affecting racialized communities first. The history of Black and Indigenous experience in the whaling industry demonstrates the importance of a longue duree perspective for considering islands, colonial history, and their power dynamics with industrial nations for relationships between species in aquatic culture.

Moreover, whaling diasporas represent an important aquapelagic chain of interspecies interdependencies and extractive impulses that have led to our current climate crisis. Black epistemologies and conceptual ecologies encourage a consciousness of these relations as necessary to address the roots/routes of racial and species exploitation and extraction. Drilling without regard for ecological relation, whether in the head of a whale or the foot of a mountain, has propelled modern life into crisis of species loss, racial violence, and social injustice. The ongoing challenges facing vulnerable coastal communities in Long Island, New York and islands elsewhere require ways of nonhumanist thinking that are responsive and responsible to the historical conditions which continue to produce precarious assemblages of being for racialized people and our mammalian kin.

\section{References}

Applebome, P. (2008, August 3). They used to say whale oil was indispensable, too. The New York Times. https://www.nytimes.com/2008/08/03/nyregion/03towns.html 
Baumgartner, M. F., Mayo, C. A., \& Kenny, R. D. (2007). Enormous carnivores, microscopic food, and a restaurant that's hard to find. In S. D. Kraus \& R. Rolland (Eds.), The urban whale: North Atlantic right whales at the crossroads (1st ed., pp. 136-169). Harvard University Press.

Bertão, D. E. (2006). The Portuguese shore whalers of California, 1854-1904. Portugese Heritage Publications of California.

Bolster, J. W. (1998). Black Jacks: African American seamen in the Age of Sail. Harvard University Press. https://doi.org/10.2307/j.ctv19m61bs

Busch, B. C. (1994). Whaling will never do for me: The American whalemen in the nineteenth century. The University Press of Kentucky.

Dolin, E. J. (2008). Leviathan: The history of whaling in America. W.W. Norton and Co.

Edwards, E. J. (2018). Whale off. Papamoa Press. (Original work published 1932)

Ellis, R. (1991). Men and whales. Knopf \& Random House.

Farr, J. (1983). A slow boat to nowhere: The multi-racial crews of the American whaling industry. The Journal of Negro History, 68(2), 159-170. https://doi.org/10.2307/2717719

Federal Writers' Project of the Works Progress Administration of Massachusetts. (1938). Whaling masters. Old Dartmouth Historical Society.

Fielding, R. (2018). The wake of the whale: Hunter societies in the Caribbean and North Atlantic. Harvard University Press. https://doi.org/10.4159/9780674989696

Foner P.S. \& Lewis R.L. (1978). The Black Worker, Volume 1: The Black Worker to 1896. Temple University Press. https://doi.org/10.2307/j.ctvn1tbr6

Foy, C. (2006). Seeking freedom in the Atlantic world. Early American Studies, 4(1), 46-77. https://www.jstor.org/stable/23546534

Fragments of the Lion Gardiner Deed. (ca. 1639-1663). [Lion Gardiner Deed, with the marks of Native American Sachems]. Center for Brooklyn History (Call no. 2016.009, Box A0021), New York City, NY, United States.

Gumbs, A. P. (2020). Undrowned: Black feminist lessons from marine mammals. AK Press.

Hayward, P. (2012). Aquapelagos and aquapelagic assemblages: Towards an integrated study of island societies and marine environments. Shima: The International Journal of Research into Island Cultures, 6(1), 1-11. https://doi.org/10.21463/shima.12.2.03

Howell, G. R. (1866). The early history of Southampton, L.I., New York, with genealogies. J.N. Hallock. http://archive.org/details/earlyhistoryofso00howel

King, T. L. (2019). The Black shoals: Offshore formations of Black and Native studies. Duke University Press. https://doi.org/10.25158/19.2.8

Kraus S. D., \& Rolland, R. (2007). The urban whale: North Atlantic right whales at the crossroads. Harvard University Press.

Laist, D. W. (2017). North Atlantic right whales: From hunted Leviathan to conservation icon. Johns Hopkins University Press. https://doi.org/10.14430/arctic4737

Lipman, A. C. (2015). The saltwater frontier: Indians and the contest for the American coast. Yale University Press. https://doi.org/10.12987/yale/9780300207668.001.0001

Malloy, M. (1990). African Americans in the maritime trades: A guide to resources in New England (Kendall Whaling Museum Monograph series, no. 6). Blue Hill Press. 
McKittrick, K. (2016). Diachronic loops/deadweight tonnage/bad made measure. Cultural Geographies, 23(1), 3-8. https://doi.org/10.1177/1474474015612716

Montauk Tribe Extinct, Is Court Edict, but Assembly Bill Would Recognize Them. (1922, Feb 17). Brooklyn Daily Eagle. Center for Brooklyn History (Pelletreau family papers, ARC. 124), New York City, NY, United States.

Morgan, P. D. (Ed.). (2018). Maritime slavery (1st ed.). Routledge.

New Bedford Whaling Museum. (2020). American offshore whaling: Crew lists. https://whalinghistory.org/av/crew/

O'Callaghan, E. B., \& Fernow, B. (Eds.). (1883). Documents relative to the colonial history of the State of New York (Vol. 14). Weed, Parsons, \& Co. https://archive.org/details/documentsrelativ14brod/page/756/

Pershing A. J., Christensen, L. B., Record, N. R., Sherwood, G. D., \& Stetson, P. B. (2010). The impact of whaling on the ocean carbon cycle: Why bigger was better. PLoS ONE, 5(8), e12444. https://doi.org/10.1371/journal.pone.0012444

Pharaoh v. Benson, New York Court of Appeals (1906). Retrieved from https://play.google.com/books/reader?id=JV0kTjJwEykC\&hl=en\&pg=GBS.PR2

Pharaoh v. Benson, 126 N.Y.S. 1035 (1910). https://casetext.com/case/pharaoh-v-benson-1

Pharaoh v. Benson, 149 N.Y.S. 438, 164 App. Div. 51 (1914). https://cite.case.law/nys/149/438/

Pharaoh, F. P. (1922). Mrs. Florence P. Pharaoh makes a correction. Brooklyn Daily Eagle, 12. Center for Brooklyn History (Pelletreau family papers, ARC. 124), New York City, NY, United States.

Pugh, J. (2016). The relational turn in island geographies: Bringing together island, sea, and ship relations and the case of the landship. Social and Cultural Geography, 17(8), 10401059. https://doi.org/10.1080/14649365.2016.1147064

Pybus, C. (2007). Billy Blue: An African American journey through empire in the long eighteenth century. Early American Studies: An Interdisciplinary Journal, 5(2), 252-287. https://doi.org/10.1353/eam.2007.0013

Reeves, R., Breiwick, J. M., \& Mitchell, E. D. (1999). History of whaling and estimated kill of right whales, balaena glacialis, in the Northeastern United States, 1620-1924. Marine Fisheries Review, 61(3), 1-36. http://aquaticcommons.org/9789/

Reilly, K. S. (1993). Slavers in disguise: American whalemen and the Slave Trade 1845-1862. The American Neptune, 53(3), 177-89. https://archive.org/details/sim americanneptune summer-1993 $53 \quad 3 /$

Rickard, M. (2018). Battle for survival - The plight of North Atlantic right whales. New York State Conservationist, 73(2), 12-15. https://www.dec.ny.gov/docs/administration pdf/1018consmag4web.pdf

Scott, J. S. (1991). Afro-American sailors and the international communication network: The case of Newport Bowers. In C. D. Howell \& R. J. Twomey (Eds.), Jack Tar in history: Essays in the history of maritime life and labour (pp. 37-52). Acadiensis Press. https://doi.org/10.2307/25143686

Sharma, N. (2019). Over two centuries: Black people in nineteenth-century Hawai‘i. American Nineteenth Century History, 20(2), 115-140. https://doi.org/10.1080/14664658.2019.1650459 
Sharpe, C. (2016). In the wake: On blackness and being. Duke University Press.

Shoemaker, N. (2015). Native American whalemen and the world. University of North Carolina Press.

Smith T. D, Reeves, R. R., Josephson, E. A., \& Lund, J. N. (2012). Spatial and seasonal distribution of American whaling and whales in the Age of Sail. PLoS ONE, 7(4), e34905. https://doi.org/10.1371/journal.pone.0034905

Spillers, H. J. (1987). Mama's baby, Papa's maybe: An American grammar book. Diacritics, 17(2), 64-81. https://doi.org/10.2307/464747

Starbuck, A. (1878). History of the American whale fishery, from its earliest inception to the year 1876. Report of the US Commissioner of Fish and Fisheries, Part I. US Government Printing Office. https://doi.org/10.5962/bhl.title.35668

Strong, J. A. (2018). America's early whalemen, Indian Shore whalers on Long Island, 1650-1750. University of Arizona Press. https://doi.org/10.2307/j.ctv47wfzc

Vickers, D. (1985). Nantucket whalemen in the deep-sea fishery: The changing anatomy of early American labor force. Journal of American History, 72(2), 277-296. https://doi.org/10.2307/1903376

Walshe, R. A., \& Stancioff, E. (2018). Small island perspectives on climate change. Island Studies Journal, 13(1), 13-24. https://doi.org/10.24043/isj.56

Wehiley, A. G. (2014). Habeas viscus: Racializing assemblages, biopolitics and Black feminist theories of the human. Duke University Press. https://doi.org/10.1215/9780822376491-005

Wynter, S. (2001). Towards the sociogenic principle: Fanon, identity, the puzzle of conscious experience, and what it is like to be "Black". In M. F. Durán-Cogan \& A. GómezMoriana (Eds.), National identities and sociopolitical changes in Latin America (1st ed., pp. 30-66). Routledge. https://doi.org/10.4324/9781315052717-8 